V. Finkelshtein, Dr. Sc. (Tech.), Prof., orcid.org/0000-0002-8016-9214, O. Iegorov, Cand. Sc. (Tech.), Assoc. Prof., orcid.org/0000-0003-2599-1624,

O. Petrenko, Dr. Sc. (Tech.), Prof., orcid.org/0000-0003-4027-4818,

O. Koliada, Cand. Sc. (Tech.), Assoc. Prof., orcid.org/0000-0003-3925-0499
O. M. Beketov National University of Urban Economy in Kharkiv, Kharkiv, Ukraine, e-mail: diaskk67@gmail.com

\title{
THE ANALYTIC-FIELD METHOD FOR CALCULATING THE SQUIRREL-CAGE INDUCTION MOTOR PARAMETERS
}

Purpose. In the existing methods for calculating induction motors, such parameters as the coefficient of flattening of the of the air-gap field curve, the differential scattering coefficient and the saturated values of the inductive scattering resistances are calculated according to empirical formulas, the calculated values of which differ significantly from the experimental ones. The aim of the article is to develop methods (based on field calculations) which take into account eccentricity, saturation, and higher harmonics and is necessary when designing asynchronous motors.

Methodology. By expanding the Fourier series of the magnetic induction distribution curve in the air gap of a saturated squirrel-cage induction motor obtained by calculating the field by the finite element method, higher harmonics are determined taking into account the saturation and the rotor axis eccentricity relative to the stator axis and the exact values of inductive resistances.

Findings. A technique has been developed that increases the accuracy of the calculation of an induction motor, which eliminates errors from empirical formulas and takes into account eccentricity, saturated values of differential and groove scattering, saturation harmonics, and a flattening of the field curve in the gap, and ultimately improves the energy performance of induction motors.

Originality. The proposed technique for improving the calculation of induction motors in starting conditions allows determining the values of starting currents and torques on the motor shaft, which differ from the experimental ones by no more than the measurement error. The research results create the prerequisites for the development of an improved methodology for calculating an induction motor in all modes of its operation, which will allow us to design highly efficient motors that meet world requirements.

Practical value. Application of the proposed methodology for calculating the parameters of induction motors can increase the efficiency of electromagnetic calculations, reduce design errors, and reduce additional costs in the manufacture of prototypes.

Keywords: starting and maximum torques, starting current, higher harmonics, saturated values of inductive resistances, bevel grooves, eccentricity, differential scattering

Introduction. When designing induction motors, it is necessary to ensure that their characteristics meet the requirements of the technical specifications and current standards. For this, it is necessary to achieve a coincidence of the calculated and experimental data. According to the existing computer program [1] for calculating induction motors, inductive resistances are not calculated accurately enough. Groove scattering and saturation coefficient are calculated by the equivalent slot open, which is calculated by empirical formulas, sometimes giving an absurd result (opening of the slot is more than tooth step). The inductive resistance of differential scattering is also calculated by the empirical formula, which far from always gives a reliable result.

Literature review. The method development for calculating inductive resistances is necessary for the induction motors design, taking into account eccentricity, saturation and higher harmonics.

A lot of works have been devoted to the uneven air gap induction motors calculation. So in [2], the air gap eccentricity influence on the electromagnetic parameters and transients in the induction motor windings is considered. The paper [3] presents electromagnetic behavior of Induction Motor through the modeling and analysis by applying multiphysics coupled Finite Element Analysis (FEA). Prediction of the magnetic flux, electromagnetic torque, stator and rotor losses are the most important issues during its design. In [4] a methodology for calculating the induction motor inductive resistances taking into account mixed eccentricity is presented. The article [5] presents a refined equivalent circuit of a synchronous reluctance motor, which allows calculating the motor torque and stator current with high accuracy, a method for determining

(C) Finkelshtein V., Iegorov O., Petrenko O., Koliada O., 2020 the longitudinal and transverse resistance when solving the problem using the finite element method is proposed.

The theoretical bases of calculation of electromagnetic quantities and time-phase relationship are presented in [6]. This is done by numerical calculations of the magnetic field in the software environment package FEMM (Finite Element Method Magnetics). A program which controls calculations and organizes the issuance of the results to a text file is created on the algorithmic language Lua. In [7] the aim is to substantially reduce the length of the transient response time in timestepping finite element (TS-FE) simulation of induction motors. This goal is pursued by means of two different techniques introduced in this paper. In the first technique, an initial guess of the magnitudes and distribution of the rotor bar currents under steady-state operation is obtained using the motor's T-equivalent circuit.

The article [8] suggested a novel method for offline induction motor parameter estimation based on sparse grid optimization algorithm. The estimated motor parameters can be further refined by using any local search method.

The work [9] contains the induction motor study results by numerical field analysis methods, which, in turn, are used for analyzing design data. But, the most problematic issues when designing induction motors were not considered, namely the eccentricity influence on starting characteristics, the inductive resistances refinement, which affects the electromagnetic calculations accuracy.

Taking into account saturation and eccentricity, it is possible to calculate the field in the air gap and in the magnetic circuit using high-performance software for modeling two-dimensional and three-dimensional electromagnetic fields ANSYS Maxwell [10]. At the same time, it seems possible to obtain induction values in the form of an array of points on 
predetermined lines (the air gap circumference or the stator and rotor grooves middle lines) depending on the angle in Fig. 4 or the groove height in Fig. 5. Then, the induction harmonics in the air gap are determined by the formulas

$$
\begin{aligned}
& B_{S_{n}}=\frac{1}{p \pi} \int_{0}^{2 \cdot p \cdot \pi} B(\alpha) \cdot \sin (n \cdot \alpha) d \alpha ; \\
& B_{C_{n}}=\frac{1}{p \pi} \int_{0}^{2 \cdot p \cdot \pi} B(\alpha) \cdot \cos (n \cdot \alpha) d \alpha ; \\
& B_{A_{n}}=\sqrt{B_{S}^{2}+B_{C}^{2}}, \quad n=1,3,5,7, \ldots,
\end{aligned}
$$

where $B_{S_{n}}, B_{C_{n}}$ and $B_{A_{n}}$ are the sinusoidal, cosine components and the $n^{\text {th }}$ harmonic amplitude, respectively; $p$ is the sum of motor poles pairs.

Since the function $B(\alpha)$ is specified numerically, to calculate the field harmonics, it is necessary to replace the integrals with the sums

$$
\begin{aligned}
& B_{S_{n}}=\sum_{i=0}^{C} B_{i} \cdot \sin \left(n \cdot \alpha_{i}\right) \cdot \frac{2}{C} ; \\
& B_{S_{n}}=\sum_{i=0}^{C} B_{i} \cdot \cos \left(n \cdot \alpha_{i}\right) \cdot \frac{2}{C},
\end{aligned}
$$

where $B_{i}$ is the induction value at the $i^{\text {th }}$ point with the angle value $\alpha_{i} ; C=1000$ is the sum of points.

Saturation has a large effect on inductive resistances. At the start-up time, the inductive scattering resistance decreases due to magnetic circuits saturation along the scattering flux paths, and the mutual induction inductive resistance increases to an unsaturated value.

New possibilities in the induction motors electromagnetic field calculation were obtained using the finite element method for the field calculations. This method quickly spread among electric machines developers. Its main advantage is that instead of directly solving the electromagnetic field differential equations, one can study the energy functional at an extreme. The solution is simplified by many times, while the solution accuracy remains high. In other words, the boundary-value problem of the partial differential direct integration equations is replaced by the variation one. The problem of vibrational statement in the energy functional study makes it possible, firstly, to obtain a solution easier and, secondly, to talk about the finite element method as a more accurate one for calculating electromagnetic forces and torques in induction motors, in comparison with traditional grapho-analytical methods based on pie charts and an idealized electric machine assumption.

To calculate according to [10], it is necessary to set the eccentricity value. The air gap in induction motors AIR80 is $0.25 \mathrm{~mm}$. If we assume that the tolerances on the locking surfaces dimensions, the hubs for the bearings, the clearance in the bearings themselves and the core bore eccentricity relative to the bed locking surfaces are such that each of them leads to an increase in the rotor axis eccentricity relative to the stator axis, then the latter will be $0.22 \mathrm{~mm}$, i.e. $88 \%$ from the air gap. In the field calculation, an $80 \%$ eccentricity is adopted.

Purpose. The aim of the article is, based on field calculations, to develop methods necessary in the design of asynchronous motors, which take into account eccentricity, saturation, and higher harmonics.

Results. It is convenient to set the currents for calculating the field for that moment in time when the current is equal to zero in one phase, and the currents are equal in the other two phases

$$
i_{1}=I_{1 \max } \cdot \sin \left(\frac{\pi}{3}\right) \cdot S_{p}=0.866 \cdot I_{1 \max } \cdot S_{p},
$$

where $i_{1}$ is the total current value in the slot when the phase current magnitude is equal to $0.866 \cdot I_{1 \max } ; I_{1 \max }$ is the phase current maximum value; $S_{p}$ is the number of conductors in the slot.

Current distribution in the rotor slots is

$$
i_{2 n}=I_{21}^{\prime} \cdot \frac{2 \cdot m \cdot \sqrt{2} \cdot W_{f}}{Z_{2}} \cdot \cos \left(\frac{2 \cdot \pi \cdot p \cdot n}{Z_{2}}\right),
$$

where $n=0,1,2, \ldots, Z_{2}-1$ is the rotor slot number; $i_{2 n}$ is the rotor current in the $n^{\text {th }}$ slot; $I_{21}^{\prime}$ the rotor current first harmonic effective value reduced to the stator; $m$ is the number of phases; $W_{f}$ is the effective number of stator winding phase turns; $Z_{2}$ is the number of rotor slots; $p$ is the number of motor poles pairs. is

Electric angle in degrees between stator and rotor currents

$$
\alpha=\arg \left(\frac{i \cdot X_{\mu 1}}{\frac{R_{21}^{\prime}}{0.8}+i \cdot\left(X_{\mu 1}+X_{2 \sigma 1}^{\prime}\right)}\right) \cdot \frac{180}{\pi},
$$

where the designations are shown in Fig. 1.

As an example in Fig. 2 shows the stator currents and squirrel-cage rotor distribution with numbers indicating their size and direction for the ADB160L6/18 two-speed elevator motor with a ratio of pole numbers $6 / 18$, with separate windings, with a power of 3 and $1 \mathrm{~kW}$, respectively, for a synchronous speed of 1000 and $333 \mathrm{rpm} / \mathrm{min}$.

The motor data and the six-pole winding are as follows: the outer stator core diameter is $272 \mathrm{~mm}$, the inner stator diameter is $180 \mathrm{~mm}$, the core length is $145 \mathrm{~mm}$, the air gap is $0.4 \mathrm{~mm}$, the number of stator slots is 54 , the number of rotor slots is 42 , the number of conductors in the stator slots is 20 .

The magnetic field lines distribution is shown in Fig. 3, and the induction distribution curve in the air gap in the short circuit mode at the pole division at the minimum gap at an $80 \%$ eccentricity is shown in Fig. 4 (under the magnetic induction distribution curve shows the stator and rotor teeth relative position).

In the short circuit mode, there is a very strong magnetic circuit saturation and saturated inductive resistances values. The induction distribution curve over the entire circumference was expanded in a Fourier series.

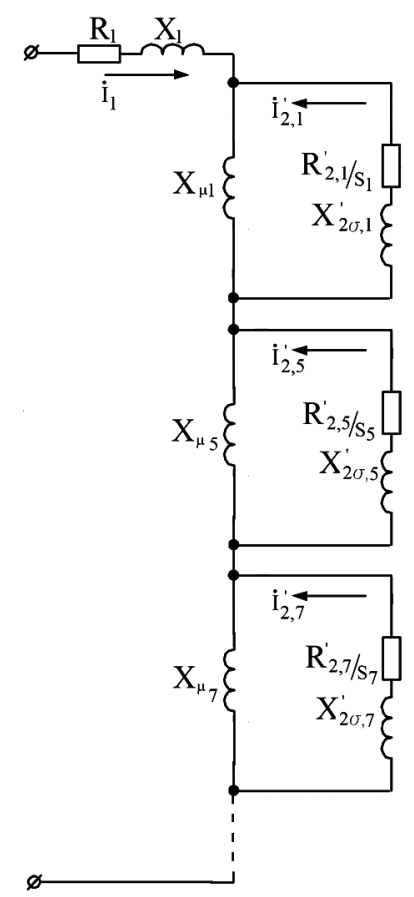

Fig. 1. Induction motor equivalent circuit taking into account the resistance of the higher harmonic components 


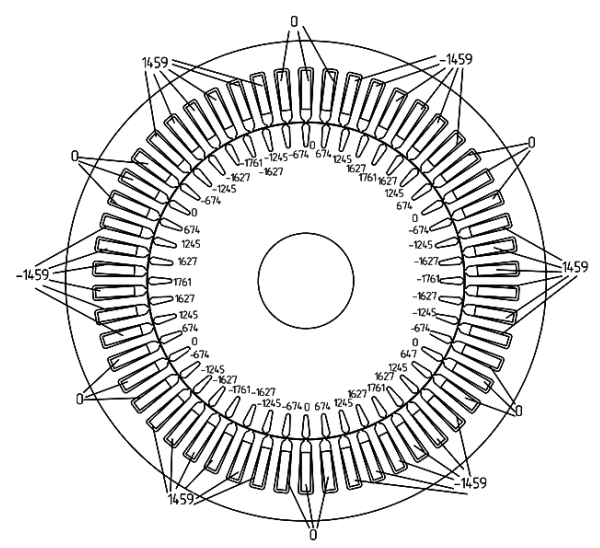

Fig. 2. Stator and rotor current distribution in the starting mode

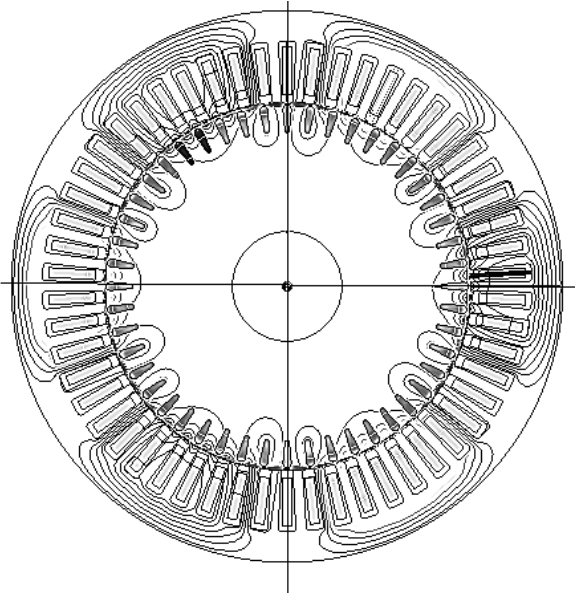

Fig. 3. Magnetic field lines in the starting mode

At the field first calculation in the air gap, higher harmonics currents are not introduced into the rotor slots. This is equivalent to the fact that the harmonics rotor branches are open. Therefore, these harmonics induction values are due to the stator current flowing through the magnetizing branches inductive resistances $X \mu \nu$ (Fig. 1).

With the known induction amplitude values of higher harmonics obtained when calculating the field in the air gap and expanding the induction distribution curve in a Fourier series, the inductive resistances values can be calculated by the formula

$$
X_{\mu v}=B_{v} \cdot W_{1} \cdot l_{1} \cdot \frac{\tau \cdot \sqrt{2} \cdot K_{v}}{\nu \cdot I_{1} \cdot \sin \left(\frac{\pi}{3}\right) \cdot 1.57},
$$

where $X \mu \nu$ is the inductive resistance of the magnetizing $v^{\text {th }}$ harmonic branch; $B_{v}, K_{v}$ are the $v^{\text {th }}$ harmonic induction am-

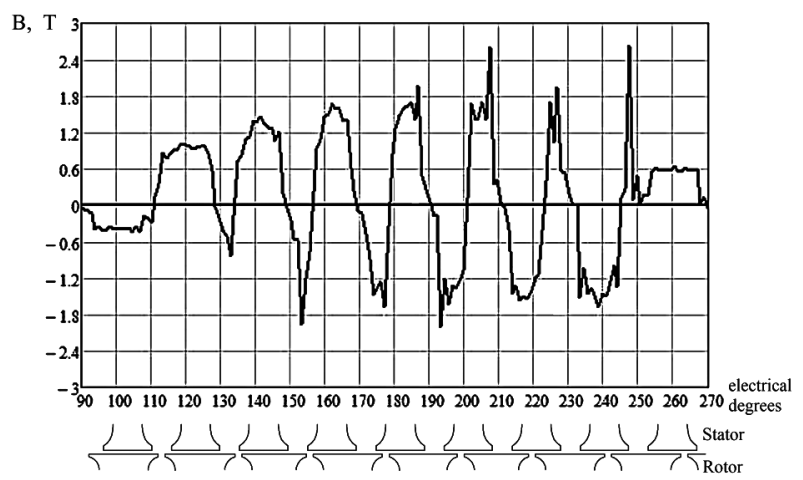

Fig. 4. Short-circuit induction distribution curve in the air gap plitude and winding coefficient, respectively; $\tau$ is the pole division; $W_{1}$ is the number of turns in the winding phase; $l_{1}$ is the core length; $v$ is any odd number.

The winding differential scattering inductance is equal to the inductive resistances sum of all the harmonics magnetizing branches $X \mu$.

Therefore, the stator differential scattering coefficient can be represented as

$$
K_{d c}=\left(\sum_{k=1}^{33} \frac{X_{\mu}(k)}{X_{\mu 1}}\right)-\frac{X_{\mu}(1)}{X_{\mu 1}},
$$

where $k$ is any odd number.

When describing the energy conversion process in the induction motor, the main attention is paid to the air gap between the machine stationary and moving parts, since the main electromagnetic field is concentrated here. For description convenience, an induction machine is idealized and all the electric and magnetic variables that characterize the field in the air gap appear to be sinusoidal dependent on temporal and spatial coordinates. But in reality there is an infinite spectrum of field harmonics in the inductions machine air gap.

The induction motor field harmonic composition contains winding harmonics of order $6 \cdot k \pm 1$, order stator tooth harmonics $\frac{k \cdot Z_{1}}{p} \pm 1$ (these harmonics winding coefficients are equal to the first harmonic winding coefficient), rotor tooth harmonics of order $\frac{k \cdot Z_{2}}{p} \pm 1$ ( $k$ is any positive integer), saturation harmonics, which are caused by the nonlinear dependence between magnetic induction and magnetizing current (including, among others, the non-coils harmonics that are multiples of three).

Saturation harmonics rotate with a synchronous speed, and winding harmonics - with a speed equal to the ratio of the synchronous frequency to the order of harmonics. Of the saturation harmonics, the third harmonic is the largest in amplitude (other harmonics that are multiples of three 9, 15,21 , and so on, can be neglected because of their smallness). It is the third harmonic that mainly determines the magnetic induction curve flattening in the air gap. The third harmonic in all three winding phases induces the same magnitude and time phase EMF. This EMF is present in phase voltages. When connecting the windings into a star, there is not third harmonic in the line voltages (usually it tries to avoid connecting the windings to a triangle, as this leads to additional losses and an increase in the windings overheating).

The third harmonic, like all higher harmonics, including winding ones, is damped by the rotor winding. The damping degree depending on the slip was determined experimentally. A frequency analyzer was connected to the winding phase and at a frequency of $150 \mathrm{~Hz}$ the EMF was measured in the slip range from 0 to $7 \%$ (nominal slip $-3.9 \%$ ). In this case, the third harmonic EMF decreased from 2.5 to $1.2 \%$ i.e. by more than 2 times. It follows that with increasing load, flattening decreases and the induction distribution curve in the air gap approaches a sinusoid.

For winding harmonics

$$
\begin{gathered}
X_{\mu}(k)=\left[D_{p_{(6 k+1) \cdot p}} \cdot \frac{K_{f}(6 \cdot k+1)}{(6 \cdot k+1)}+D_{p_{(6 k-1) \cdot p}} \cdot \frac{K_{f}(6 \cdot k-1)}{(6 \cdot k-1)}\right] \times \\
\times W_{1} \cdot l_{1} \cdot \frac{\tau \cdot 10^{-4} \cdot \sqrt{2} \cdot \pi \cdot f}{1.57 \cdot I_{0} \cdot 1.221}
\end{gathered}
$$

for $k=0$, the second term (1) in square brackets is 0 .

For stator tooth harmonics 


$$
\begin{aligned}
& X_{Z 1}(k)=\left[D_{p_{\left(\frac{Z 1}{p}+1\right)}} \cdot \frac{K_{f}\left(\frac{Z 1}{p} \cdot k+1\right)}{\left(\frac{Z 1}{p} \cdot k+1\right)}+D_{P_{\left(\frac{Z 1}{p} k-1\right)}} \cdot \frac{K_{f}\left(\frac{Z 1}{p} \cdot k-1\right)}{\left(\frac{Z 1}{p} \cdot k-1\right)}\right] \times \\
& \times W_{1} \cdot l_{1} \cdot \frac{\tau \cdot 10^{-4} \cdot \sqrt{2} \cdot \pi \cdot f}{1.57 \cdot I_{0} \cdot 1.221} ; \\
& X_{Z 2}(k)=\left[D_{P_{\left(\frac{Z_{k}}{p}+1\right)}} \cdot \frac{K_{f}\left(\frac{Z 2}{p} \cdot k+1\right)}{\left(\frac{Z 2}{p} \cdot k+1\right)}+D_{P_{\left(\frac{Z 2}{p}-1\right)}} \cdot \frac{K_{f}\left(\frac{Z 2}{p} \cdot k-1\right)}{\left(\frac{Z 2}{p} \cdot k-1\right)}\right] \times \\
& \times W_{1} \cdot l_{1} \cdot \frac{\tau \cdot 10^{-4} \cdot \sqrt{2} \cdot \pi \cdot f}{1.57 \cdot I_{0} \cdot 1.221} .
\end{aligned}
$$

The rotor axis eccentricity relative to the stator axis has a great influence on the engine operation. Eccentricity significantly affects the performance of the motor and can quickly bring it into an inoperative state.

According to field calculations, not only the differential scattering coefficient can be determined, but also the inductive resistance from the slot scattering flux. By calculating, using a computer program [10], the induction tangential components in the rotor slot (Fig. 5) and the stator (Fig. 6), were determined in the investigated motor.

The distribution of magnetic induction in the form of a point coordinates two-dimensional array was determined along the rotor slots $a b$ and the stator slots $A B$. Then the inductive resistance from slot scattering can be determined by the formula

$$
X_{p 1,2}=\sum_{J=0}^{C_{1} 1} \frac{\left(O 1_{j .1} \cdot \frac{h_{p 1,2}}{\tilde{N} 1}\right) \cdot l_{1} \cdot 10^{-7} \cdot 4 \cdot \pi \cdot f \cdot W_{1}}{I \cdot 1.221},
$$

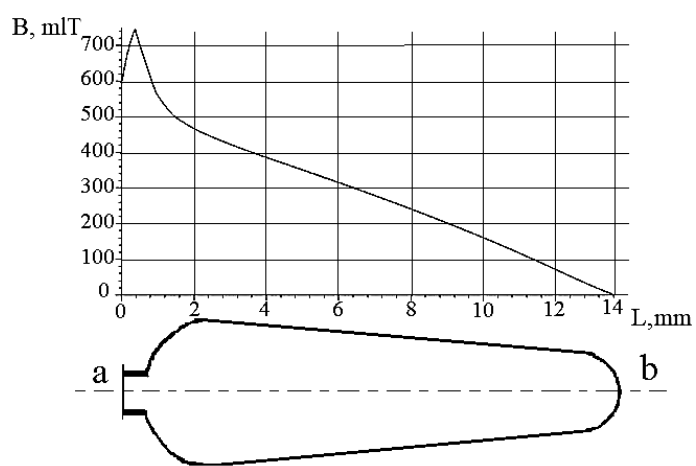

Fig. 5. The tangential component of induction in the groove of the rotor

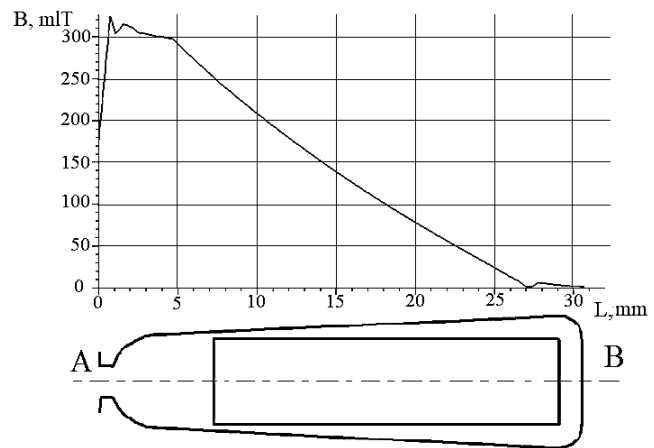

Fig. 6. The tangential component of induction in the groove of the stator where $O 1_{j .1}$ are the ordinates of the curve points array in Fig. 5 and Fig. $6 ; h_{p 1,2}-$ the height of the stator slot -1 or rotor slot -2 . $C 1$ is the number of rows in the $O 1$ array.

Inductive parameters obtained by the field calculation results, taking into account saturation, eccentricity and flattening for the motor ADB160L6 are given in Table. 1. Also, comparisons were made of the ADB160L6 induction motor starting characteristics obtained using the existing methodology, using the saturation estimation technique proposed in the article and with experimental data.

The results are presented in Table. 2.

Practical testing of the technique. In the specialized design bureau UKRELEKTROMASH (Kharkiv), an experiment was conducted using a special laboratory bench (Fig. 7). On two, four, and six-pole motors, the eccentricity gradually changed, the phase EMF of tooth harmonics, the current, and the power consumption were measured.

The principle of operation of the laboratory bench. Racks 2 are fixed on the frame 1 , on which sliding bearings are installed 3. The grease of the bearings is carried out using two cap

\begin{tabular}{|c|c|c|c|c|c|c|c|}
\hline \multirow{3}{*}{ 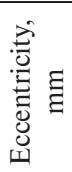 } & \multirow{2}{*}{\multicolumn{3}{|c|}{$\begin{array}{l}\text { Total winding harmonics } \\
\text { and saturation } \\
\text { harmonics, } T\end{array}$}} & \multicolumn{4}{|c|}{ Tooth harmonics, $T$} \\
\hline & & & & \multicolumn{2}{|c|}{ Stator } & \multicolumn{2}{|c|}{ Rotor } \\
\hline & $l^{s t}$ & $3^{r d}$ & $5^{\text {th }}$ & $17^{h}$ & $19^{\text {th }}$ & $15^{\text {th }}$ & $17^{h}$ \\
\hline 0 & 1.055 & 0.078 & 0 & 0.08 & 0.36 & 0.274 & 0.08 \\
\hline 0.1 & 1.055 & 0.078 & 0 & 0.08 & 0.36 & 0.275 & 0.08 \\
\hline 0.2 & 1.055 & 0.078 & 0.012 & 0.079 & 0.368 & 0.28 & 0.079 \\
\hline 0.3 & 1.053 & 0.074 & 0.018 & 0.076 & 0.378 & 0.288 & 0.076 \\
\hline
\end{tabular}
grease nipples 4 . The carriage is fixed on the frame on the rails 5 .

Table 1

Dependences of the harmonics of an induction motor on the eccentricity of the rotor

Table 2

Comparison of the results of the calculated starting characteristics with experimental

\begin{tabular}{|c|l|c|c|}
\hline & & $\begin{array}{c}\text { Starting } \\
\text { moment, Nm }\end{array}$ & $\begin{array}{c}\text { Starting } \\
\text { current, A }\end{array}$ \\
\hline 1 & Existing calculation method & 114.6 & 61.6 \\
\hline 2 & The proposed calculation method & 91.2 & 53.7 \\
\hline 3 & Test results & 95.4 & 52.3 \\
\hline
\end{tabular}

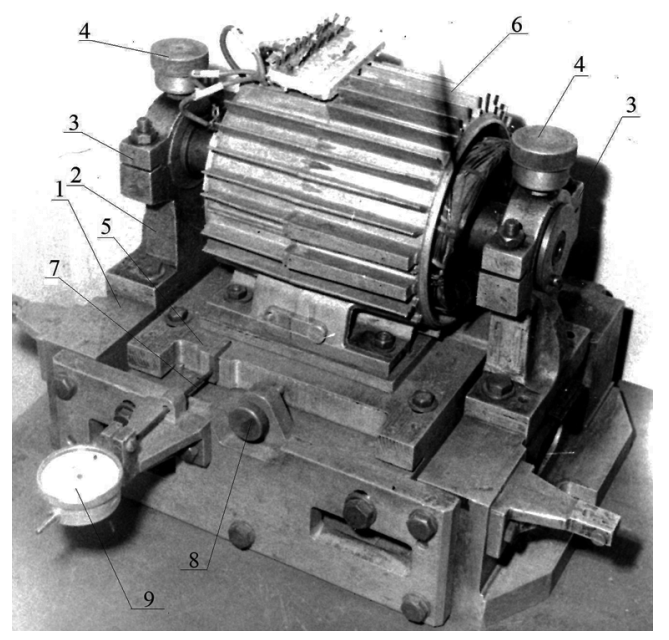

Fig. 7. The engine laboratory bench 
The stator of the tested motor is mounted on the carriage 6 . The rod 7 of the indicator clock abuts the carriage and by adjusting the eccentricity of the screw 8 , the indicator clock 9 shows the offset value. The division price of the indicator clock is $0.01 \mathrm{~mm}$.

Experimentally, using a special laboratory stand, it was found that:

- on bipolar motors due to eccentricity, steel losses increase by $25 \%$;

- on four-pole motors, there are practically no changes;

- on six-pole motors, large spurious moments occur and even at no-load the motor stops.

With eccentricity, the tooth harmonics sharply increase, and the winding harmonics change insignificantly, which is completely consistent with [11].

Conclusions. The existing methodology and program used many empirical formulas, which often led to large errors. With an advent of ANSYS Maxwell, a high-performance software for modeling two-dimensional and three-dimensional electromagnetic fields, it became possible to increase the calculation accuracy to eliminate errors from empirical formulas and take into account eccentricity, saturated values of differential and groove scattering, saturation harmonics, flattening the field curve in the gap and, ultimately, improving energy performance of induction motors.

\section{References.}

1. Finkelshtein, V. B. (2019). Computer program for checking the calculation of three-phase induction motors. Certificate of copyright registration for work No. 84510. Ukraine.

2. Magdanova, K. R. (2017). The effect of rotor eccentricity on the energy characteristics of an induction motor. Nauka-rastudent, 06(042). Retrieved from http://nauka-rastudent. ru/42/4274/.

3. Kumar, Mr J. Ravi, \& Basavaraja Banakara (2017). Finite element analysis in the estimation of air-gap torque and surface temperature of induction machine. Materials science and engineering conference series, (225), 46-56. https://doi. org/10.1088/1757-899X/225/1/012116.

4. Bespalov, V.Ya., Kovarskij, M. E., \& Sidorov, A. O. (2018). The study of pulsations of the electromagnetic moment of synchronous machines with permanent magnets with integer and fractional q values. Elektrichestvo, (5), 45-51.

5. Iegorov, O., Iegorova, O., \& Kundenko, M. (2019). The Influence of the Phase Angle Between the Rotor Magnetic Axis and the Stator Winding Current Vector on the Synchronous Reluctance Motor Efficiency. IEEE International Conference on Modern Electrical and Energy Systems (MEES), (pp. 62-65). https://doi.org/10.1109/MEES.2019.8896480.

6. Milykh, V.I. (2016). The numerical-field analysis of the magnetic field and the electrical quantities in the turbogenerator stator under autonomous unbalanced loading. Elektrotehnika $i$ elektromehanika, (5), 16-22. https://doi. org/10.20998/2074-272X.2016.1.05.

7. Koti, H. N. (2019). On Shortening the Numerical Transient in Time-Stepping Finite Element Analysis of Induction Motors: Method Implementation. IEEE International Electric Machines \& Drives Conference (IEMDC), (pp. 1157-1162). https://doi.org/10.1109/IEMDC.2019.8785306.

8. Duan, F. (2016). Induction motor parameter estimation using sparse grid optimization algorithm. IEEE Transactions on Industrial Informatics, 12(4), 1453-1461. https://doi.org/ 10.1109/TII.2016.2573743.

9. Milykh, V.I. (2018). Numerical-field analysis of the adequacy of design data for three-phase asynchronous motors and a method for their refinement on this basis. Tekhnichna Elektrodynami$k a$, (1), 47-55. https://doi.org/10.15407/techned2018.01.047. 10. Finkelshtein, V. B., Yegorov, O. B., Yegorova, O. Yu., \& Gyetya, A. M. (2018). Schedule in the Fourier series of the curve of the distribution of magnetic induction in the air gap of electric machines. Certificate of copyright registration for work No. 83322, Ukraine.
11. Tikhonova, O., Malygin, I., \& Plastun, A. (2017). Electromagnetic calculation for induction motors of various designs by ANSYS Maxwell. International Conference on Industrial Engineering, Applications and Manufacturing (ICIEAM), (pp. 224-226). https://doi.org/10.1109/ICIEAM.2017.8076294.

\section{Аналітико-польовий розрахунок параметрів асинхронних двигунів з короткозамкненим ротором}

\author{
В. Б. Фінкельштейн, О. Б. Сгоров, О. М. Петренко, \\ О. Ю. Коляда
}

Харківський національний університет міського господарства імені О.М. Бекетова, м. Харків, Україна, e-mail: diaskk67@gmail.com

Мета. В існуючих методиках розрахунку асинхронних двигунів такі параметри як коефіцієнт сплощення кривої поля в повітряному зазорі, коефіцієнт диференціального розсіювання й насичені значення індуктивних опорів розсіювання розраховуються за емпіричними формулами, розрахункові величини за якими істотно відрізняються від експериментальних. Метою статті є розробка методики (на основі польового розрахунку), що враховує ексцентриситет, насичення й вищі гармоніки та необхідної при проектуванні асинхронних двигунів.

Методика. Розкладанням у ряд Фур'є кривої розподілу магнітної індукції в повітряному зазорі насиченого асинхронного двигуна з короткозамкненим ротором, отриманої розрахунком поля методом кінцевих елементів, визначаються вищі гармоніки 3 урахуванням насичення та ексцентриситету осі ротора щодо осі статора й точні значення індуктивних опорів.

Результати. Розроблена методика, що підвищує точність розрахунку асинхронного двигуна та дозволяє виключити похибки від емпіричних формул і враховувати ексцентриситет, насичені величини диференціального і пазової розсіювання, гармоніки насичення, сплощення кривої поля в зазорі та, у кінцевому рахунку, покращувати енергетичні показники асинхронних двигунів.

Наукова новизна. Запропонована методика уточнення розрахунків асинхронних двигунів у пускових режимах дозволяє визначати величини пускових струмів і моментів на валу двигуна, що відрізняються від експериментальних не більше ніж на похибку вимірювань. Результати досліджень створюють передумови до розробки уточненої методики розрахунку асинхронного двигуна у всіх режимах його роботи, що дозволить проводити проектування високоефективних двигунів, які відповідають світовим вимогам.

Практична значимість. Застосування запропонованої методики розрахунку параметрів асинхронних двигунів дозволяє підвищити ефективність електромагнітних розрахунків, зменшити похибки при проектуванні, скоротити додаткові витрати при виготовленні дослідних зразків.

Ключові слова: пусковий і максимальний моменти, пусковий струм, вищі гармоніки, насичені значення індуктивних опорів, скіс пазів, ексцентриситет, диференціальне розсіювання

\section{Аналитико-полевой расчет параметров асинхронных двигателей с короткозамкнутым ротором}

\section{В. Б. Финкельштейн, А. Б. Егоров, А. Н. Петренко, О. Ю. Коляда}

Харьковский национальный университет городского хозяйства имени А.Н.Бекетова, г. Харьков, Украина, e-mail: diaskk67@gmail.com 
Цель. В существующих методиках расчёта асинхронных двигателей такие параметры как коэффициент уплощения кривой поля в воздушном зазоре, коэффициент дифференциального рассеяния и насыщенные значения индуктивных сопротивлений рассеяния рассчитываются по эмпирическим формулам, расчётные величины по которым существенно отличаются от экспериментальных. Целью статьи является разработка методики (на основе полевого расчёта), учитывающей эксцентриситет, насыщение и высшие гармоники, и необходимой при проектировании асинхронных двигателей.

Методика. Разложением в ряд Фурье кривой распределения магнитной индукции в воздушном зазоре насыщенного асинхронного двигателя с короткозамкнутым ротором, полученной расчётом поля методом конечных элементов, определяются высшие гармоники с учётом насыщения и эксцентриситета оси ротора относительно оси статора и точные значения индуктивных сопротивлений.

Результаты. Разработана методика, повышающая точность расчёта асинхронного двигателя, позволяющая исключить погрешности от эмпирических формул и учитывать эксцентриситет, насыщенные величины дифференциального и пазового рассеяния, гармоники насыщения, уплощение кривой поля в зазоре и, в конечном счё- те, улучшать энергетические показатели асинхронных двигателей.

Научная новизна. Предложенная методика уточнения расчетов асинхронных двигателей в пусковых режимах позволяет определять величины пусковых токов и моментов на валу двигателя, отличающихся от экспериментальных не более чем на погрешность измерений. Результаты исследований создают предпосылки к разработке уточненной методики расчета асинхронного двигателя во всех режимах его работы, что позволит проводить проектирование высокоэффективных двигателей, которые соответствуют мировым требованиям.

Практическая значимость. Применение предлагаемой методики расчета параметров асинхронных двигателей позволяет повысить эффективность электромагнитных расчетов, уменьшить погрешности при проектировании, сократить дополнительные затраты при изготовлении опытных образцов.

Ключевые слова: пусковой и максимальный моменты, пусковой ток, высшие гармоники, насыщенные значения индуктивных сопротивлений, скос пазов, эксцентриситет, дифференциальное рассеяние

Recommended for publication by M. M. Babaiev, Doctor of Technical Sciences. The manuscript was submitted 27.09.19. 